\title{
FOLIARLY APPLIED OSMOTIC PRESERVATIVE CONTRIBUTES TO PEAR (PYRUS COMMINUS) LEAF AND ROOT NUTRITIONAL STATUS UNDER DROUGHT STRESS
}

\author{
KÜÇÜKYUMUK, Z. \\ Isparta Uygulamali Bilimler University, Department of Soil Science and Plant Nutrition, \\ Faculty of Agriculture, Isparta, Turkey \\ e-mail: zelihakucukyumuk@isparta.edu.tr; phone: +90-533-748-1642 \\ (Received 24 $4^{\text {th }}$ Jan 2021; accepted $14^{\text {th }}$ May 2021)
}

\begin{abstract}
Drought is a threat to arid and semiarid zone agriculture worldwide, its importance is better understood day by day. Fruit trees need irrigation and fertilization for yield and fruit quality and since pear trees are perennial plants their water and nutrition consumption varies compared to annual plants. Glycine betaine is an osmotic preservative that adjusts the osmotic balance within the tissues. There are a limited number of studies on the effect of glycine betaine on drought stress on leaf and root nutrient uptake of pear trees. The aim of the study was to evaluate whether foliarly-applied glycine betaine could reduce the negative effects of drought on mineral nutrition of pear tree in leaves and roots. This study was carried out in order to reveal the nutritional variations of the pear nursery trees under drought stress and to evaluate the influences of osmoprotectant applications. This study had three drought levels and four glycine betaine levels with three replications and there were three plants in each replication. Foliar GB applications are advantageous even in the regions which have drought problems and nutrient concentrations may increase under drought with glycine betaine. In general, the dose of $10 \mathrm{mg} \mathrm{L}^{-1} \mathrm{~GB}$ application was appropriate for pear nurseries under drought stress.
\end{abstract}

Keywords: different irrigation treatments, glycine betaine, nutrition, pear

\section{Introduction}

Drought is one of the most important restricting factor on crop production and mineral nutrition uptake. Water has an important role in nutrient transport, regulation of temperature, and in photosynthesis. Water deficiency may cause mineral nutrition problems besides plant production and growth restrictions. From soil solution to rhizosphere, mineral nutrition transportation mostly depends on the water in the soil. Drought and membrane permeability can cause a decrease in the transpiration rate. Although soils were fertilized, nutrient deficiencies might be caused by drought stress, as the physiochemical properties of the soil can lead to a decreased mobility and absorbance of nutrients (Silva et al., 2010). Determining the drought stress effect on plant nutrition is important to limit the loss of plant production and plant nutrition caused by deficit water.

Excessive fertilization triggers negative results like excessive plant vigor, decreased yield and fruit skin color, abortion of flowers as well as increased incidence of fungal diseases on leaves and fruit (Brunetto et al., 2015).

World pear production is constantly increasing and the amount of production in 2018 was 24 million tonnes and China, Argentina, USA, Italy and Turkey are the leading countries in terms of pear production (FAO, 2020). To ensure the commercial sustainability in pear production water is one of the most important factor and the countries especially having threat of drought have begun to gain momentum on studies related with water stress (Küçükyumuk, 2020).

The roots of fruit trees are as effective as their leaves and their root systems have an important role in growth, development and fruiting by interacting with systems. Since pear 
trees are perennial, their fertilization should differ from annual plants greatly. The amount of nutrients in the root zone affects the nutrition of the tree by rootstock, variety, soil chemical and physical properties, irrigation and fertilization methods (Küçükyumuk and Erdal, 2011). Determining the amount of nutrients uptaken by roots, contributes more efficient use of fertilizers.

Glycine betaine (GB) is a low molecular weight nitrogen compound involved in osmoregulation. Under drought stress conditions, especially its accumulation in the cytoplasm increases strongly. Betaine is significant for the adaptation of plants to drought because its functions as a compatible solute to counterosmotic perturbation caused by high vacuolar concentrations of inorganic ions such as $\mathrm{Cl}^{-}$and $\mathrm{Na}^{+}$, which can limit cytoplasmic metabolism. Since it is soluble in water glycine betaine is a very influential compatible solute and does not carry a net charge balance of the cytoplasm has no effect and preserves the activity of pyruvate kinase isolated and also reduces $\mathrm{K}^{+}$for enzyme activation (Marschner, 2012). Glycine betaine naturally occurs in the organisms and can be used in many different plant species. Glycine betaine adjust the osmotic balance within the tissues and acts as an osmotic protector (Korteniemi, 2007). Glycine betaine biosynthesis is increased in many plant species under water deficiency conditions. The effectiveness of external GB application may vary depending on the plant growth period, application level and number of applications (Shahbaz et al., 2011). There is limited studies with GB application on the effects of nutrient uptake in plants.

Several studies have indicated that foliar glycine betaine application alleviates the negative effects of drought stress such as tobacco leaf development (Agboma et al., 1997), olive (Roussos et al., 2010; Denexa et al., 2012), E. Japonica (loquat) (Jin et al., 2015), maize dry matter, and grain yield (Zhang et al., 2009), sunflower weight, biomass production (Iqbal et al., 2005) and in chestnut it was revealed with morphological changes that with $75 \%$ water deficit level and GB application had the best growth performance (Hozman, 2016). There are very few studies whether foliarly-applied glycine betaine could reduce the negative effects of drought on mineral nutrition of plants (Mahmood et al., 2009; Khadouri, 2015; Mahdavi et al., 2017; Noroozlo et al., 2019).

The aim of this study is to determine the effect of glycine betaine under drought stress on nutrient concentrations in pear trees.

\section{Materials and methods}

\section{Experimental area and plant material}

The study was carried out in semi-open (non-heated) greenhouse on the experiment field at Fruit Research Institute (Isparta-Turkey) in 2019. The young pear trees used in the study were one-year-old and Deveci (Pyrus Comminus L. "Deveci") variety grafted onto OHxF 333 rootstock were used. Due to the fact that Deveci pear variety is cultivated at high rate in Turkey (Sakaldaş and Gündoğdu, 2016) it was selected for this study. Trees were planted in pots in early April. We selected the pear trees having similar growth vigour before this experiment started. They are placed into a greenhouse with clear plastic cover on the top, sides open in order to prevent the pots to be affected by the rainfall.

\section{The mixed soil and irrigation water}

The mixed soil (15 liters) of soil: peat: manure (1:1:0.5 ratios) was placed into 15 liters pots. Irrigation water $\left(\mathrm{EC}=0.3 \mathrm{dS} \mathrm{\textrm {m } ^ { - 1 }}\right.$ and $\left.\mathrm{SAR}=1.04\right)$ used for the trees was supplied 
from a well at Fruit Research Institute. Classification was realized according to the US Salinity Laboratory Graphical System. According to this system, the salinity values of the irrigation water, which are in 250-750 ECx $10^{6}$ range, are included in category $\mathrm{C}_{2}$, and in category $S_{1}$ in terms of SAR value (USSL, 1954). Irrigation water was $C_{2} S_{1}$ class, which is suitable for irrigation.

\section{Irrigation and glycine betaine treatments}

Before the study started, the mixed soil in the five pots without plant was saturated with water. Then the pots were covered with aluminum foil to prevent evaporation. After no leaking was observed from the pots, the pot weight was considered as field capacity. Irrigation water was applied to the potted trees every four days when the soil water reached to field capacity until July $16^{\text {th }}$. The water stress treatments started on July $16^{\text {th }}$ when the temperatures were higher and finished on September 6th. There were three different irrigation treatments in the experiment. Treatments were; $\mathrm{I}_{100}$ treatment: available soil water reached field capacity for each irrigation, $100 \%$ (control), $\mathrm{I}_{50}$ treatment; $50 \%$ of irrigation water was used than in $\mathrm{I}_{100}$ treatment (50\% water deficit, moderate stress), $\mathrm{I}_{25}$ treatment; $25 \%$ of irrigation water was used than in $\mathrm{I}_{100}$ treatment ( $75 \%$ water deficit, severe stress). The field capacity value of the mixed soil in the pots is determined in order to figure out the irrigation water amount used in every irrigation treatment.

Glycine betaine $(\mathrm{GB})$ was applied two times: 1 . on July $15^{\text {th }}$ before starting water stress applications, 2 . On July $30^{\text {th }}$ after starting water stress applications. It was applied in four different doses: $\mathrm{GB}_{0}$ : no GB, control; $\mathrm{GB}_{1}: 1 \mathrm{mg} \mathrm{L}^{-1}$; $\mathrm{GB}_{5}: 5 \mathrm{mg} \mathrm{L}^{-1}$ and $\mathrm{GB}_{10}: 10 \mathrm{mg}$ $\mathrm{L}^{-1} \mathrm{~GB}$ was applied to leaves all trees as liquid form by using backpack sprayer. GB was not applied pear trees in $\mathrm{I}_{100}$ treatment. Each drought treatment ( $\mathrm{I}_{50}$ and $\mathrm{I}_{25}$ ) had four different GB doses including zero doses. Therefore, there were 9 different treatments with three drought and four GB doses in this study.

Before each treatment, the pots in the $\mathrm{I}_{100}$ treatment were weighed, and the missing water was given to the pots by using a tape (with a 2-litre volume and $50 \mathrm{ml}$ accuracy) to assure that the pots reach the field capacity. To calculate the amount of water used in other treatments, the average water amount used in the first treatment was taken into consideration. The irrigation water that leaked into the base plate was added back into the pots.

As fertilization $1.4 \mathrm{~kg}$ ammonium nitrate, $2 \mathrm{~kg}$ mono ammonium nitrate, $0.5 \mathrm{~kg}$ potassium nitrate was given to 81 pots with irrigation before starting water stress application date.

\section{Soil properties and plant analysis}

Initial properties of the soil mixture used in this experiment were the followings: $\mathrm{pH}$ 7.3 (1:2.5-soil: water) and soil extract EC, $0.19 \mathrm{dS} \mathrm{m}^{-1}$, clay in texture, $75 \%$ saturation, $\mathrm{CaCO}_{3}, 14.9 \%$, organic material 5.5 (Knudsen et al., 1982), available P $130 \mathrm{mg} \mathrm{kg}^{-1}$ (Olsen et al., 1954), extractable K $64 \mathrm{mg} \mathrm{kg}^{-1}$, extractable Ca $6040 \mathrm{mg} \mathrm{kg}^{-1}$, extractable Mg $1519 \mathrm{mg} \mathrm{kg}^{-1}$ (Jackson, 1973), extractable Fe $59 \mathrm{mg} \mathrm{kg}^{-1}$, extractable Zn $3 \mathrm{mg} \mathrm{kg}^{-1}$, extractable Mn $12 \mathrm{mg} \mathrm{kg}^{-1}$, extractable $\mathrm{Cu} 2.6 \mathrm{mg} \mathrm{kg}^{-1}$.

Leaf samples were collected from that year's middle shoots 12 weeks after full bloom turning around the tree, leaves put in paper bags and brought to laboratory. Leaves were washed with tap and distilled water and dried at $65 \pm{ }^{\circ} \mathrm{C}$ until stable weight, after dried the leaves ground. After the trial was over, the roots were cut from below the grafting point. To cleanse soil, it was washed first with tap later with distilled water and 
dried at $65 \pm{ }^{\circ} \mathrm{C}$ until stable weight. Plant tissues were digested with nitric acid $\left(\mathrm{HNO}_{3}\right)$ using a microwave-digestion system (CEMMars 5, manufactured by CEM Corp., USA). Plant (leaf and root) ion concentration $(\mathrm{Ca}, \mathrm{Mg}, \mathrm{K}, \mathrm{Fe}, \mathrm{Cu}, \mathrm{Zn}, \mathrm{Mn}, \mathrm{B}$ ) was determined by inductively coupled plasma optical emission spectrometry (ICP-OES). Total nitrogen was analysed according to Kjeldahl method. Phosphorus concentrations of samples were determined with a spectrophotometer (Shimadzu UV-1208) at $430 \mathrm{~nm}$ according to the vanadomolybdophosphoric acid method (Kacar and İnal, 2008).

\section{Experimental design and statistical analysis}

This experiment was designed according to experimental design at randomized plots with three replications and there were three plants in each replication. The analysis of variance (ANOVA) test for the data was conducted with JUMP software program and the differences among treatments were compared by means using LSD test and correlation analysis were made.

\section{Results and discussion}

As seen in Table 1, drought stress reduced the $\mathrm{N}$ concentration of the pear leaves and found important statistically. Control (without drought stress) treatment had $3.4 \% \mathrm{~N}$ concentrations. Both deficit irrigations $\left(\mathrm{I}_{50}\right.$ and $\left.\mathrm{I}_{25}\right)$ reduced $\mathrm{N}$ concentrations to $3.2 \%$ and \% 3.3, however, leaves $\mathrm{N}$ concentrations increased with glycine betaine applications. The highest concentration of glycine betaine increased $\mathrm{N}$ concentrations, I50 drought stress by applying $10 \mathrm{mg} \mathrm{kg}^{-1} \mathrm{~GB}$ increased to $3.6 \% \mathrm{~N}$ concentration. Similar increase occured in $\mathrm{I}_{25}$ drought stress, $10 \mathrm{mg} \mathrm{kg}^{-1} \mathrm{~GB}$ increased $\mathrm{N}$ concentration to $3.5 \%$. In a study Mohammadipour and Souri (2019), determined that application of glycine betaine increased leaf concentrations of nitrogen at $10 \mathrm{mg} \mathrm{L}^{-1}$ compared to the control plants. The difference between the phosphorus concentrations were not significant at $\mathrm{p}<0.05$ level.

Table 1. The effect of GB under drought stress on macro nutrient concentrations of leaves

\begin{tabular}{c|c|c|c|c|c}
\hline Treatments $(\%)$ & $\mathbf{N}$ & $\mathbf{P}$ & $\mathbf{K}$ & $\mathbf{C a}$ & $\mathbf{M g}$ \\
\hline $\mathrm{I}_{100}(\mathrm{Control})$ & $3.4 \mathrm{~b}^{* *}$ & $0.12^{n s}$ & $2.85 \mathrm{abc}^{*}$ & $3.08 \mathrm{a}^{*}$ & $1.35 \mathrm{~b}^{* *}$ \\
$\mathrm{I}_{50}-\mathrm{GB}_{0}$ & $3.2 \mathrm{c}$ & 0.11 & $2.61 \mathrm{bcd}$ & $3.00 \mathrm{a}$ & $1.33 \mathrm{bc}$ \\
$\mathrm{I}_{50}-\mathrm{GB}_{1}$ & $3.5 \mathrm{a}$ & 0.12 & $2.90 \mathrm{a}$ & $3.08 \mathrm{a}$ & $1.23 \mathrm{~d}$ \\
$\mathrm{I}_{50}-\mathrm{GB}_{5}$ & $3.4 \mathrm{~b}$ & 0.11 & $2.86 \mathrm{ab}$ & $2.79 \mathrm{ab}$ & $1.20 \mathrm{~d}$ \\
$\mathrm{I}_{50}-\mathrm{GB}_{10}$ & $3.6 \mathrm{a}$ & 0.11 & $2.96 \mathrm{a}$ & $2.63 \mathrm{~b}$ & $1.29 \mathrm{c}$ \\
$\mathrm{I}_{25}-\mathrm{GB}_{0}$ & $3.3 \mathrm{~b}$ & 0.11 & $2.54 \mathrm{~d}$ & $3.08 \mathrm{a}$ & $1.37 \mathrm{ab}$ \\
$\mathrm{I}_{25}-\mathrm{GB}_{1}$ & $3.1 \mathrm{~d}$ & 0.12 & $2.59 \mathrm{~cd}$ & $3.02 \mathrm{a}$ & $1.21 \mathrm{~d}$ \\
$\mathrm{I}_{25}-\mathrm{GB}_{5}$ & $3.3 \mathrm{~b}$ & 0.11 & $2.61 \mathrm{bcd}$ & $3.11 \mathrm{a}$ & $1.10 \mathrm{e}$ \\
$\mathrm{I}_{25}-\mathrm{GB}_{10}$ & $3.5 \mathrm{a}$ & 0.12 & $2.71 \mathrm{abcd}$ & $2.55 \mathrm{~b}$ & $1.40 \mathrm{a}$ \\
\hline
\end{tabular}

ns: not significant, $* \mathrm{p}<0.05, * * \mathrm{p}<0.01$

The $\mathrm{K}^{+}$concentrations of GB-applied leaves under drought stress were found significant. While control had $2.85 \% \mathrm{~K}^{+}$concentrations, with the $\mathrm{I}_{25}$ deficit irrigation conditions the leaves $\mathrm{K}^{+}$concentrations decreased to $2.54 \% \mathrm{~K}$ concentrations. Potassium has a remarkable role for the water regulation and high mobility in plants, in the cytoplasm there is sufficient $\mathrm{K}^{+}$and helps osmotic potantiel of plants (Mengel and Kirkby, 2001). In plants water stress affect the potassium accumulation in leaves and 
interact with $\mathrm{K}^{+}$concentrations (Restrepo-Diaz et al., 2008). Similar results were found by Mahouachi (2007) and Restrepo Diaz et al. (2008) that decreased concentrations of $\mathrm{K}^{+}$in banana plants and olive plants can be observed under drought conditions in the leaves. Our results showed that leaves applied with $10 \mathrm{mg} \mathrm{kg}^{-1} \mathrm{~GB}$ had the highest $\mathrm{K}^{+}$ concentrations. Compared with control plants, GB-applied plants had higher $\mathrm{K}^{+}$ concentrations in maize cultivars (Ashraf and Foolad, 2007). Our results are consistent with Shahbaz et al. (2011) they found that, foliar-applied GB reduced the negative effects of water stress by increasing plant biomass, shoot length, transpiration rate, root $\mathrm{P}$, and $\mathrm{N}$ contents and in shoot only $\mathrm{K}^{+}$in both cultivars under stress.

While control had $3.08 \% \mathrm{Ca}^{2+}$ concentration, $\mathrm{GB}$ application with $\mathrm{I}_{25} \mathrm{Ca}^{2+}$ concentration was $2.55 \%$ and with $\mathrm{I}_{50} \mathrm{Ca}^{2+}$ concentration was $2.63 \%$. $\mathrm{Hu}$ and Schmidhalter (2005) determined slight reduce of $\mathrm{Ca}^{2+}$ compared to phosphorus and potassium. Sardans et al. (2008) found decreasing tendency on $\mathrm{Ca}^{2+}$ content under drought in soil. Under water stress without GB application $\mathrm{Ca}^{2+}$ concentrations slightly reduced, however, with GB application under stress caused higher decrease in a study exogenous application of GB did not affect leaf $\mathrm{Ca}^{2+}$ concentrations (Mahmood et al., 2009). Also, our results are consistent with Khadouri (2015) in alfalfa calcium concentrations were reduced with the drought applications and decreased with applying glycine betaine.

In our research, GB application and drought stress decreased $\mathrm{Mg}^{2+}$ concentrations of the pear leaves except $10 \mathrm{mg} \mathrm{kg}^{-1}$ with $\mathrm{I}_{25}$. The conditions of the soil and rhizospher under drought and available water conditions affected the magnesium concentrations and physiological parameters under drought stress, the plant roots are not able to absorbe enough magnesium for the growing plant (Merhaut, 2007). Brown et al. (2006) found reductions in $\mathrm{Mg}^{2+}$ uptake in both the roots and shoots of Spartina alterniflora under drought conditions. In a cowpea study (Khadouri, 2015) GB applications increased the $\mathrm{Mg}^{2+}$, GB has significant effects to fix the drought stress on the Cowpea.

As seen in Table 2, the application of GB and drought affected Fe concentrations in pear leaves. The leaves Fe concentrations increased with the applications. While water deficit applications slightly increased Fe concentrations, the GB applications especially 10 $m g \mathrm{~L}^{-1}$ increased the Fe uptake. The GB application with the $\mathrm{I}_{50}$ had $72 \mathrm{mg} \mathrm{kg}^{-1} \mathrm{Fe}$ concentration, $\mathrm{I}_{25}$ had $68 \mathrm{mg} \mathrm{kg}^{-1} \mathrm{Fe}$ concentration, when the control treatment had $54 \mathrm{mg} \mathrm{kg}^{-1} \mathrm{Fe}$ concentration. In a study application of glycine in lettuce had significant increase in iron concentrations (Noroozlo et al., 2019) under drought and in another study, analysis of variance results showed important effects when plants under drought treatment researchers found significantly higher uptake of Fe in their shoots (Brown et al., 2006).

Table 2. The effect of GB under drought stress on micro nutrient concentrations of leaves

\begin{tabular}{c|c|c|c|c|c}
\hline Treatments $\left(\mathbf{m g ~ k g} \mathbf{~ g}^{-1}\right)$ & $\mathbf{F e}$ & $\mathbf{Z n}$ & $\mathbf{M n}$ & $\mathbf{C u}$ & $\mathbf{B}$ \\
\hline $\mathrm{I}_{100}(\mathrm{Control})$ & $54 \mathrm{~d}^{* *}$ & $6.7 \mathrm{bc}$ & $38^{n s}$ & $7.2^{\text {ns }}$ & $45 \mathrm{c}^{*}$ \\
$\mathrm{I}_{50}-\mathrm{GB}_{0}$ & $58 \mathrm{~cd}$ & $6.1 \mathrm{c}$ & 41 & 7.0 & $46 \mathrm{bc}$ \\
$\mathrm{I}_{50}-\mathrm{GB}_{1}$ & $63 \mathrm{bc}$ & $8.1 \mathrm{~b}$ & 40 & 6.7 & $44 \mathrm{c}$ \\
$\mathrm{I}_{50}-\mathrm{GB}_{5}$ & $64 \mathrm{bc}$ & $8.6 \mathrm{~b}$ & 42 & 7.1 & $46 \mathrm{bc}$ \\
$\mathrm{I}_{50}-\mathrm{GB}_{10}$ & $72 \mathrm{a}$ & $6.8 \mathrm{bc}$ & 49 & 5.6 & $54 \mathrm{a}$ \\
$\mathrm{I}_{25}-\mathrm{GB}_{0}$ & $58 \mathrm{~cd}$ & $6.1 \mathrm{c}$ & 42 & 6.9 & $46 \mathrm{bc}$ \\
$\mathrm{I}_{25}-\mathrm{GB}_{1}$ & $63 \mathrm{bc}$ & $9.0 \mathrm{a}$ & 38 & 7.5 & $46 \mathrm{bc}$ \\
$\mathrm{I}_{25}-\mathrm{GB}_{5}$ & $65 \mathrm{abc}$ & $6.8 \mathrm{bc}$ & 40 & 6.6 & $44 \mathrm{c}$ \\
$\mathrm{I}_{25}-\mathrm{GB}_{10}$ & $68 \mathrm{ab}$ & $7.5 \mathrm{bc}$ & 47 & 6.7 & $51 \mathrm{ab}$ \\
\hline
\end{tabular}

ns: not significant, ${ }^{*} \mathrm{p}<0.05, * * \mathrm{p}<0.01$ 
The zinc concentrations of pear leaves decreased with drought treatments increased with GB applications compared to control conditions. Zinc deficiencies can occur with low soil moisture (Hu and Schmidhalter, 2005) and zinc nutrition may influence the water relation such as stomatal conductance in plants (Khan et al., 2004). Our results are consistent with Mohammadipour and Souri (2019) they found that application of all glycine levels increased zinc leaf concentrations compared to the control conditions of coriander.

Even $\mathrm{Mn}^{2+}$ concentrations were not found significant statistically the GB applications under drought had higher $\mathrm{Mn}^{2+}$ results compared to control conditions. The applications of GB increased $\mathrm{Mn}^{2+}$ concentrations in cowpea under drought (Khadouri, 2015). Copper concentrations were not found significant and the results decreased with GB applications.

The B concentrations with GB applications under drought found significant statistically. Water deficit conditions did not change B concentrations results too much, however, under drought conditions, GB applications improved leaves B concentrations. While control had $45 \mathrm{mg} \mathrm{kg}^{-1} \mathrm{~B}$ concentration, the $\mathrm{I}_{50}$ and $\mathrm{I}_{25}$ applications with $10 \mathrm{mg}$ $\mathrm{L}^{-1} \mathrm{~GB}$ had 54 and $51 \mathrm{mg} \mathrm{kg}^{-1} \mathrm{~B}$ concentrations.

The pear tree roots $\mathrm{N}, \mathrm{P}, \mathrm{K}^{+}, \mathrm{Ca}^{2+}$ and $\mathrm{Mg}^{2+}$ concentrations were given in Table 3 . Application of glycine betaine increased leaf concentrations of nitrogen to $2.4 \%$ under $\mathrm{I}_{50}$ at $10 \mathrm{mg} \mathrm{L}^{-1}$ level and to $2.5 \%$ under $\mathrm{I}_{25}$ water at $1 \mathrm{mg} \mathrm{L}^{-1}$ level. The phosphorus and potassium concentrations of the roots were not found significant. The results of the roots phosphorus concentrations were not varied. The potassium concentrations of the roots increased under water deficit conditions at all glycine levels. All glycine levels except for $5 \mathrm{mg} \mathrm{L}^{-1} \mathrm{I}_{50}$ increased root $\mathrm{Ca}^{2+}$ concentration. Leaf $\mathrm{Ca}^{2+}$ content had the highest concentration by glycine applied at $10 \mathrm{mg} \mathrm{L}^{-1}$. Our study showed that while roots $\mathrm{Ca}^{2+}$ concentrations increased, the leaves $\mathrm{Ca}^{2+}$ concentrations decreased with the applications. The distribution and uptake of $\mathrm{Ca}^{2+}$ in plants are affected by many factors. Root uptake seems to be independent of metabolic inhibitors but transfer to shoots is strongly decreased by such inhibitors (Wallace and Mualler, 1980). The cations such as $\mathrm{K}^{+}, \mathrm{Mg}^{2+}$ limit $\mathrm{Ca}^{2+}$ uptake and distribution directly or indirectly, their effects are more pronounced at low $\mathrm{Ca}$ concentrations than at high. Calcium transition in plants is unidirectional, moving up from the roots and generally routed to meristematic zones and young tissue (Hanger, 1979). Bitter pit is caused by $\mathrm{Ca}^{2+}$ deficiency in pear fruit and decreases the quality of the pears.

Table 3. The effect of GB under drought stress on macro nutrient concentrations of roots

\begin{tabular}{c|c|c|c|c|c}
\hline Treatments $(\%)$ & $\mathbf{N}$ & $\mathbf{P}$ & $\mathbf{K}$ & $\mathbf{C a}$ & $\mathbf{M g}$ \\
\hline $\mathrm{I}_{100}(\mathrm{Control})$ & $2.3 \mathrm{ab}^{*}$ & $0.17^{n s}$ & $0.29^{n s}$ & $1.75 \mathrm{c}^{* *}$ & $0.33 \mathrm{bcd}^{*}$ \\
$\mathrm{I}_{50}-\mathrm{GB}_{0}$ & $2.3 \mathrm{ab}$ & 0.16 & 0.35 & $1.97 \mathrm{bc}$ & $0.32 \mathrm{bcd}$ \\
$\mathrm{I}_{50}-\mathrm{GB}_{1}$ & $1.5 \mathrm{c}$ & 0.17 & 0.30 & $2.0 \mathrm{abc}$ & $0.31 \mathrm{~cd}$ \\
$\mathrm{I}_{50}-\mathrm{GB}_{5}$ & $2.1 \mathrm{ab}$ & 0.17 & 0.31 & $1.71 \mathrm{c}$ & $0.30 \mathrm{~d}$ \\
$\mathrm{I}_{50}-\mathrm{GB}_{10}$ & $2.4 \mathrm{a}$ & 0.18 & 0.33 & $2.22 \mathrm{ab}$ & $0.39 \mathrm{a}$ \\
$\mathrm{I}_{25}-\mathrm{GB}_{0}$ & $2.0 \mathrm{abc}$ & 0.16 & 0.29 & $2.14 \mathrm{ab}$ & $0.33 \mathrm{bcd}$ \\
$\mathrm{I}_{25}-\mathrm{GB}_{1}$ & $2.5 \mathrm{a}$ & 0.19 & 0.31 & $2.40 \mathrm{a}$ & $0.36 \mathrm{abc}$ \\
$\mathrm{I}_{25}-\mathrm{GB}_{5}$ & $2.0 \mathrm{abc}$ & 0.17 & 0.38 & $2.29 \mathrm{ab}$ & $0.35 \mathrm{abc}$ \\
$\mathrm{I}_{25}-\mathrm{GB}_{10}$ & $1.8 \mathrm{bc}$ & 0.16 & 0.38 & $2.35 \mathrm{a}$ & $0.3 \mathrm{~b}$ \\
\hline
\end{tabular}

ns: not significant, ${ }^{*} \mathrm{p}<0.05, * * \mathrm{p}<0.01$ 
While the $\mathrm{Mg}^{2+}$ concentrations of roots decreased with GB applications levels except $10 \mathrm{mg} \mathrm{L}^{-1}(0.39 \%)$ under $\mathrm{I}_{50}$, increased with GB applications levels except $10 \mathrm{mg} \mathrm{L}^{-1}$ $(0.30 \%)$ under $\mathrm{I}_{25}$ levels compared to control conditions $(0.33 \%)$.

The micro elements of the roots except Fe concentrations were not found significant as seen in Table 4. The iron concentrations found significant statistically. The iron concentrations of pear leaves decreased with drought treatments but increased with GB applications at $10 \mathrm{mg} \mathrm{L}^{-1}\left(150 \mathrm{mg} \mathrm{kg}^{-1}\right.$ and $\left.144 \mathrm{mg} \mathrm{kg}^{-1}\right)$ level compared to control conditions (139 mg kg $\mathrm{g}^{-1}$ ). Our results are not consistent with Sardans et al. (2008), in their study they found adverse results of $\mathrm{Fe}$ root results, they found higher $\mathrm{Fe}$ concentrations in roots under drought.

Table 4. The effect of GB under drought stress on micro nutrient concentrations of roots

\begin{tabular}{c|c|c|c|c|c}
\hline Treatments $\left(\mathbf{m g ~ k g} \mathbf{~}^{-1}\right)$ & Fe & Zn & Mn & Cu & B \\
\hline $\mathrm{I}_{100}(\mathrm{Control})$ & $139 \mathrm{abc}^{*}$ & $14^{n s}$ & $30^{n s}$ & $17^{n s}$ & $44^{n s}$ \\
$\mathrm{I}_{50}-\mathrm{GB}_{0}$ & $127 \mathrm{abc}$ & 14 & 32 & 15 & 44 \\
$\mathrm{I}_{50}-\mathrm{GB}_{1}$ & $112 \mathrm{c}$ & 13 & 32 & 15 & 42 \\
$\mathrm{I}_{50}-\mathrm{GB}_{5}$ & $118 \mathrm{bc}$ & 14 & 37 & 14 & 50 \\
$\mathrm{I}_{50}-\mathrm{GB}_{10}$ & $150 \mathrm{ab}$ & 18 & 45 & 15 & 54 \\
$\mathrm{I}_{25}-\mathrm{GB}_{0}$ & $111 \mathrm{c}$ & 16 & 39 & 16 & 46 \\
$\mathrm{I}_{25}-\mathrm{GB}_{1}$ & $160 \mathrm{a}$ & 14 & 37 & 15 & 46 \\
$\mathrm{I}_{25}-\mathrm{GB}_{5}$ & $115 \mathrm{bc}$ & 14 & 39 & 14 & 48 \\
$\mathrm{I}_{25}-\mathrm{GB}_{10}$ & $144 \mathrm{abc}$ & 14 & 41 & 16 & 51 \\
\hline
\end{tabular}

ns: not significant, ${ }^{*} \mathrm{p}<0.05$

Even $\mathrm{Mn}^{2+}$ and $\mathrm{B}$ concentrations were not found significant, the $\mathrm{Mn}^{2+}$ and $\mathrm{B}$ concentrations of the roots increased with GB applications under drought compared to control. While $\mathrm{Mn}^{2+}$ concentrations of the roots were $30 \mathrm{mg} \mathrm{kg}^{-1}$, with the $\mathrm{I}_{50}$ and $\mathrm{I}_{25} \mathrm{~GB}$ applications $\mathrm{Mn}^{2+}$ concentrations were $45 \mathrm{mg} \mathrm{kg}^{-1}$ and $41 \mathrm{mg} \mathrm{kg}$. The $\mathrm{Mn}^{2+}$ concentrations increase with GB applications were similar with B concentrations. While the roots of the control had $44 \mathrm{mg} \mathrm{kg}^{-1} \mathrm{~B}$ concentrations with the $10 \mathrm{mg} \mathrm{L}^{-1} \mathrm{~GB}$ applications under $\mathrm{I}_{50}$ and $\mathrm{I}_{25}$ roots had $54 \mathrm{mg} \mathrm{kg}^{-1}$ and $51 \mathrm{mg} \mathrm{kg}^{-1} \mathrm{~B}$ concentrations.

Roots are important organs that supply water and nutrients and translocate them to upper parts of the plants. Roots bind the plant to the soil and keep the plant upright. The leaf $\mathrm{Mn}$ and $\mathrm{B}$ concentrations correlated with root $\mathrm{Mn}$ and $\mathrm{B}$ concentrations (Figure 1 and Figure 2). The other leaf nutrient concentrations did not correlate with root nutrient elements. This can be due to the trees crown system is not large enough, in the following years the correlation can be seen in terms of nutrition.

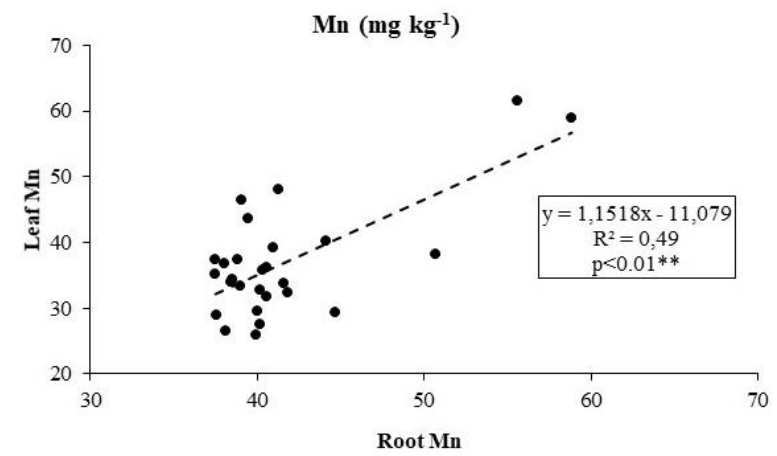

Figure 1. The correlation of leaf and root Mn concentrations 


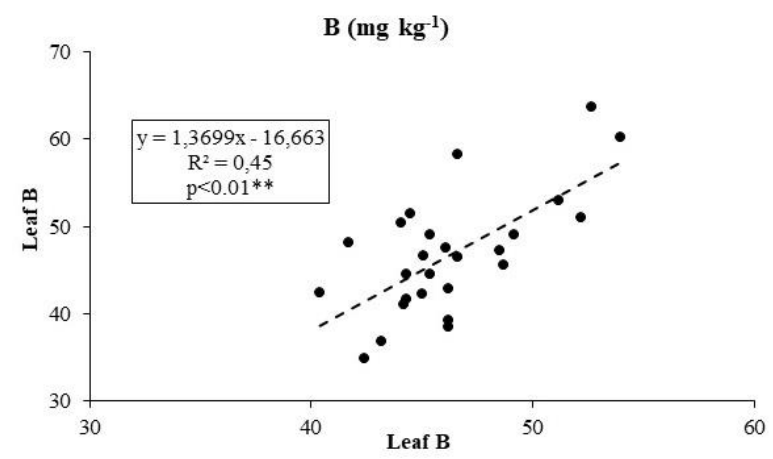

Figure 2. The correlation of leaf and root B concentrations

\section{Conclusions}

This study has showed that glycine betaine affected positively pear nutrient concentrations under drought stress conditions. Drought stress caused decrease in plant nutrients uptake. We can say that foliar GB applications are advantageous even in the regions which have drought problems and nutrient concentrations may increase under drought with glycine betaine. In general, the dose of $10 \mathrm{mg} \mathrm{L}^{-1} \mathrm{~GB}$ application was appropriate for pear nurseries under water deficiencies. Hence, the use of glycine betaine could result with appropriate use of soil nutrients. In the following years the application dose can be increased as the tree grows. This study was conducted in pots under controlled conditions, it could be adapted to field conditions. This experiment should be studied at pear trees which are on yield age.

\section{REFERENCES}

[1] Agboma, P. C., Sinclair, T. R., Jokinen, K., Peltonen-Sainio, P., Pehu, E. (1997): An evaluation of the effect of exogenous glycinebetaine on the growth and yield of soybean: timing of application, watering regimes and cultivars. - Field Crops Research 54(1): 5164.

[2] Ashraf, M., Foolad, M. (2007): Roles of Glycine Betaine and Proline in Improving Plant Abiotic Stress Resistance. - Environmental and Experimental Botany 5: 206-216. 10.1016/j.envexpbot.2005.12.006.

[3] Brown, C. E., Pezeshki, S. R., DeLaune, R. D. (2006): The effect of salinity and soil drying on nutrient uptake and growth of Spartina alterniflora in a simulated tidal system. - Environmental and Experimental Botany 58: 140-148.

[4] Brunetto, G., Melo, G. W. B., Toselli, M., Quartieri, M., Tagliavini, M. (2015): The Role of Mineral Nutrition on Yields and Fruit Quality in Grapevine, Pear and Apple. - Revista Brasileira de Fruticultura 37(4): 1089-1104. https://dx.doi.org/10.1590/0100-2945$103 / 15$.

[5] Denaxa, N. K., Roussos, P. A., Damvakaris, T., Stournaras, V. (2012): Comparative effects of exogenous glycine betaine, kaolin clay particles and ambiol on photosynthesis, leaf sclerophylly indexes and heat load of olive cv. Chondrolia Chalkidikis under drought. - Scientia Horticulturae 137: 87-94.

[6] FAO (2020): Food and Agriculture Organization of the United Nations. http://www.fao.org/faostat.

[7] Hanger, B. C. (1979): The movement of calcium in plants. - Communications in Soil Science and Plant Analysis 10(1-2): 171-193. DOI: 10.1080/00103627909366887. 
[8] Hozman, S. (2016): Su Stresi ve Osmoprotektan Uygulamalarının Kestane Fidanlarında Fizyolojik ve Morfolojik Özellikler Üzerine Etkileri. - Adnan Menderes Üniversitesi, Fen Bilimleri Enstitüsü, Yüksek Lisans Tezi.

[9] Hu, Y., Schmidhalter, U. (2005): Drought and salinity: A comparison of their effects on mineral nutrition of plants. - Journal of Plant Nutrition and Soil Science 168: 541-549.

[10] Iqbal, N., Ashraf, M. Y., Ashraf, M. (2005): Influence of water stress and exogenous glycinebetaine on sunflower achene weight and oil percentage. - Int. J. Sci. Tech. 2: 155160.

[11] Jackson, M. L. (1973): Soil Chemical Analysis. - Prentice-Hall, Inc., Englewood Cliffs, N.S.

[12] Jin, P., Zhang, Y., Shan, T., Huang, Y., Xu, J., Zhang, Y. (2015): Low Temperature Conditioning Alleviates Chilling Injury in Loquat Fruit And Regulates Glycine Betaine Content And Energy Status. - Agricultural and Food Chemistry 63: 3654-3659.

[13] Kacar, B., Inal, A. (2008): Plant Analysis. - Nobel, 1241 Ankara, Turkey, p.115-140.

[14] Khadouri, H. K. (2015): Effects of Glycine Betaine on Plant Growth and Performance of Alfalfa (Medicago Sativa L.) \& Cowpea (Vigna Unguiculata L. Walp.) Within Water Deficit Conditions. - Theses 187.

[15] Khan, H. R., Mc Donald, G. K., Rengel, Z. (2004): Zinc fertilization and water stress affects plant water relations, stomatal conductance and osmotic adjustment in chickpea (Cicer arientinum L.). - Plant and Soil 267: 271-284.

[16] Knudsen, D., Peterson, G. A., Pratt, P. F. (1982): Lithium, Sodium and Potassium. - In: Page, A. L. (ed.) Methods of Soil Analysis, Part 2. Chemical and Microbiological Properties. Exchangeable Cations, pp. 159- 165.

[17] Korteniemi, M. (2007): A Short Description of Glisin betain (Bluestim). - Marketing and Registration Verdera Oy Luoteisrinne 2 P.O. Box 5 Fl-02271 Espoo, Finland.

[18] Küçükyumuk, Z., Erdal, İ. (2011): Rootstock and Cultivar Effect on Mineral Nutrition, Seasonal Nutrient Variation and Correlations Among Leaf, Flower and Fruit Nutrient Concentrations in Apple Trees. - Bulgarian Journal of Agricultural Science 17(5): 633641.

[19] Küçükyumuk, C. (2020): Drought Response of Young Pear Trees (Pyrus Comminus). Applied Ecology and Environmental Research 18(6): 7769-7781.

[20] Mahdavi, S., Kafi, M., Fallahi, E., Shokrpour, M., Tabrizi, L. (2017): Drought and biostimulant impacts on mineral nutrients, ambient and reflected light-based chlorophyll index, and performance of perennial ryegrass. - Journal of Plant Nutrition 40(16): 22482258. DOI: $10.1080 / 01904167.2016 .1237650$.

[21] Mahmood, T., Ashraf, M., Shahbaz, M. (2009): Does exogenous application of glycinebetaine as a pre-sowing seed treatment improve growth and regulate some key physiological attributes in wheat plants grown under water deficit conditions? - Pak. J. Bot. 41: 1291-1302.

[22] Mahouachi, J. (2007): Growth and mineral nutrient content of developing fruit on banana plants (Musa acuminata AAA, 'Grand Nain') subjected to water stress and recovery. Journal of Horticultural Science and Biotechnology 82: 839-844.

[23] Marschner, P. (2012): Marshner's Mineral Nutrition of Plants. - Third Edition, 672p.

[24] Mengel, K., Kirkby, E. A. (2001): Principles of Plant Nutrition (4th ed.). - International Potash Institute, Switzerland, 687p.

[25] Merhaut, D. J. (2007): Magnesium. - In: Barker, A. V., Pilbeam, D. J. (eds.) Handbook of Plant Nutrition (1st ed.). CRC Taylor and Francis, NY, pp. 145-181.

[26] Mohammadipour, N., Souri, M. K. (2019): Effects of different levels of glycine in the nutrient solution on the growth, nutrient composition, and antioxidant activity of coriander (Coriandrum sativum L.). - Acta Agrobot 72(1): 1759. https://doi.org/10.5586/aa.1759. 
[27] Noroozlo, Y. A., Souri, M. K., Delshad, M. (2019): Stimulation Effects of Foliar Applied Glycine and Glutamine Amino Acids on Lettuce Growth. - Open Agriculture 4(1): 164172.

[28] Olsen, S. R., Cole, V., Watanabe, F. S., Dean, L. A. (1954): Estimations of available phosphorus in soils by extractions with sodium bicarbonate. - U.S. Dept. Of Agric. Cric. pp. 939-941.

[29] Restrepo-Diaz, H., Benlloch, M., Fernández-Escobar, R. (2008): Plant water stress and $\mathrm{K}^{+}$starvation reduce absorption of foliar applied $\mathrm{K}^{+}$by olive leaves. - Scientia Horticulturae 116: 409-413.

[30] Roussos, P. A., Denaxa, N. K., Damvakaris, T., Stournaras, V., Argyrokastritis, I. (2010): Effect of alleviating products with different mode of action on physiology and yield of olive under drought. - Scientia Horticulturae 125: 700-711.

[31] Sakaldaş, M., Gündoğdu, M. A. (2016): The Effects of Preharvest 1- Methylcyclopropene (Harvista) Applications on Fruit Drop and Maturity of 'Deveci' Pear Cultivar. - Fruit Science (1 Special Edition), pp. 105-111.

[32] Sardans, J., Peñuelas, J., Ogaya, R. (2008): Drought's impact on $\mathrm{Ca}, \mathrm{Fe}, \mathrm{Mg}$, Mo and S concentration and accumulation patterns in the plants and soil of a Mediterranean evergreen Quercus ilex forest. - Biogeochemistry 87: 49-69.

[33] Shahbaz, M., Masood, Y., Perveen, S., Ashraf, M. (2011): Is foliar applied glycinebetaine effective in mitigating the adverse effects of drought stress on wheat (Triticum aestivum L.). - Journal of Applied Botany and Food Quality 84: 192-199.

[34] Silva, E. C., Nogueira, R. J. M. C., Silva, M. A., Albuquerque, M. (2010): Drought Stress and Plant Nutrition. - Plant Stress, Global Science Books. Plant Stress 5 (Special Issue 1), pp. 32-41.

[35] U.S. Salinity Laboratory Staff (1954): Diagnosis and Improvement of Saline and Alkalin Soils. - Agricultural Handbook No. 60., California, USA.

[36] Wallace, A., Mueller, R. T. (1980): Calcium uptake and distribution in plants. - Journal of Plant Nutrition 2(1-2): 247-256. DOI: 10.1080/01904168009362774.

[37] Zhang, L. X., Li, S. X., Liang, Z. S. (2009): Differential plant growth and osmotic effects of two maize (Zea mays L.) cultivars to exogenous glycinebetaine application under drought stress. - Plant Growth Regul. 58: 297-305. 